\title{
Notes on Hawaiian Snake Eels (Pisces: Ophichthidae), with Comments on Opbichthus bonaparti ${ }^{1}$
}

\author{
John E. McCosker ${ }^{2}$
}

\begin{abstract}
The 22 ophichthid eel species of the Hawaiian Islands (including Johnston and the Northwestern Hawaiian Islands) are reviewed, and a key to their identification is provided. New Hawaiian records of Indo-Pacific species include Callechelys catostoma and Ophichthus bonaparti. Callechelys lutea is reported from Johnston Island. Hawaiian and Johnston Island ophichthid species comprise: Apterichtus flavicaudus, Brachysomophis crocodilinus, B. benshawi, Callechelys catostoma, C. lutea, Cirrbimuraena playfairii, Ichtbyapus vulturis, Leiuranus semicinctus, Muraenichthys schultzei, Myrichthys colubrinus, M. magnificus, Ophichtbus bonaparti, O. erabo, O. kunaloa, O. polyophthalmus, Phaenomonas cooperae, Pbyllophichtbus xenodontus, Schismorbynchus labialis, Scbultzidia jobnstonensis, Scolecenchelys cookei, S. gymnota, and S. pubioilo. Additional data are provided for the rare deep-water species Ophichthus kunaloa. The following synonymies are proposed: Ophisurus chrysospilos Bleeker, Poecilocephalus markworti Kaup, Ophichthys episcopus Castelnau, and Opbichtbys garretti Günther =Ophichtbus bonaparti (Kaup); and Opbichthus retifer Fowler $=$ Ophichthus erabo (Jordan \& Snyder). The endemism and distribution of Hawaiian and Johnston Island ophichthids $(22.7 \%)$ are discussed and compared with those of muraenid eels. Vertebral formulas are provided for all species to facilitate the identification of leptocephali.
\end{abstract}

The SNAKe Eels and worm eels (family Ophichthidae) of the Hawaiian Archipelago (including Johnston Island and the Northwestern Hawaiian Islands) comprise 22 species distributed among 14 genera, making them the sixth most speciose family of Hawaiian fishes. Most species are pale, inhabit sand and mud bottoms, and are rarely encountered, but some are strikingly marked and can be seen at the surface at night, particularly during breeding periods. They, along with the morays, have intrigued students of Hawaiian eels and often appear in Hawaiian legend and lore (Pukui 1902, Colum 1937, McCosker 1979). Although inadequately sampled, the eel fauna of Johnston Island contains the most speciose fish family (Muraenidae, with 30 species), and

${ }^{1}$ Manuscript accepted 11 May 2001.

2 California Academy of Sciences, San Francisco, California 94118 (E-mail: jmccosker@calacademy.org).

Pacific Science (2002), vol. 56, no. 1:23-34 (C) 2002 by University of Hawai'i Press.

All rights reserved the ophichthids are among the top 10 (Kosaki et al. 1991). The actual abundance of ophichthids throughout their range, however, is underestimated as a result of their burrowing behavior, and the ability to characterize many of these forms, many lacking coloration and others entirely devoid of fins, is difficult at best. Vertebral numbers appear to be the most useful character to differentiate populations and species of these eels, and on that basis ophichthids appear to have nearly the same level of endemism as all of the Hawaiian shorefishes.

Jordan and Evermann (1905) were the first to treat the Hawaiian ophichthid fauna, followed by Gosline (1951), Gosline and Brock (1960), and McCosker (1979). Since my earlier review, Callechelys lutea was photographed and collected at Johnston Island, two specimens (one each) of the widespread IndoPacific ophichthid species Callechelys catostoma and Ophichtbus bonaparti have been discovered in Hawaiian waters, and recent revisionary studies of ophichthid genera have changed the nomenclature and taxonomic status of several species. In attempting to identify the 
Hawaiian specimen of Opbicbthus bonaparti I uncovered several synonymies of that species that were previously unreported. And finally, I have made an extensive survey of the vertebral numbers of several Hawaiian ophichthid species (including extralimital examples) and include those data in the key to assist in the identification of ophichthid leptocephali.

\section{MATERIALS AND METHODS}

Measurements are straight line, made either with a $300-\mathrm{mm}$ ruler with $0.5-\mathrm{mm}$ gradations (for total length, trunk length, and tail length) and recorded to the nearest $0.5 \mathrm{~mm}$ or with a $1-\mathrm{m}$ ruler with $1-\mathrm{mm}$ gradations and recorded to the nearest $1 \mathrm{~mm}$. All other measurements were made with dial calipers or dividers and recorded to the nearest $0.1 \mathrm{~mm}$. Total length represents the tip of the snout to the tail tip; head length is measured from the snout tip to the posterodorsal margin of the gill opening; trunk length is taken from the end of the head to midanus; body length is head plus trunk length. Maximum body depth does not include the median fins. Vertebral counts (which include the hypural) were taken from radiographs. Additional vertebral data of type specimens were taken from Böhlke (1982) and from Smith (1994). Vertebral notation and definitions are described in Böhlke (1982). The mean vertebral formula is expressed as the average of predorsal, preanal, and total vertebrae. In the case of those ophichthids that lack anal fins (species of the genera Apterichtus, Ichtbyapus, and Phaenomonas), the number cited reflects the posterior margin of the anus rather than the origin of the anal fin. Total vertebrae may include specimens extralimital to Hawai'i if the populations are presumed to be continuous. I follow Eschmeyer (1998) regarding the publication dates and authorship of taxa in this study. Institutional abbreviations follow those of Leviton et al. (1985). Other abbreviations are as follows: DFO, dorsal fin origin; HL, head length; MVF, mean vertebral formula; SL, standard length; TL, total length; $\mathrm{TV}$, total vertebrae; and VF, vertebral formula.

\section{KEY TO THE OPHICHTHID EELS OF JOHNSTON AND THE HAWAIIAN ISLANDS}

1a. Caudal fin rays conspicuous, confluent with dorsal and anal fins; tail tip flexible; gill openings midlateral, a constricted opening; pectoral fins absent in Hawaiian species ... Subfamily Myrophinae........................................... 2

1b. Tail tip a hard or fleshy finless point; gill openings midlateral to entirely ventral, unconstricted; pectoral fins present in some species ... Subfamily Ophichthinae ....... 7

2a. A prominent median toothed groove on ventral side of snout, bordered by dermal folds, extending forward to anterior nostrils; anterior nostrils elongated tubes equal to eye in length; TV 132-139; MVF 20/48/136 ........ Schismorbynchus labialis (Seale, 1917)

2b. No prominent groove bordered by dermal folds on ventral side of snout; anterior nostrils less than eye in length.............................................. 3

3a. Teeth absent on vomer, absent or embedded on intermaxilla, those on maxilla and dentary minute or villiform; DFO behind anus; TV 153-159; MVF 75/51/155 .... Schultzidia jobnstonensis (Schultz \& Woods, 1949)

3b. Teeth present on intermaxilla, maxilla, dentary, and vomer; DFO either before or behind anus................................................... 4

4a. Posterior nostril entirely outside mouth; teeth on maxilla, dentary, and vomer in broad bands; snout bluntly rounded; TV 123-130; MVF 47/46/126...

. Muraenichthys schultzei Bleeker, 1857

4b. Posterior nostril inside mouth, covered externally by a flap; teeth uniserial or biserial, not in broad bands; snout either blunt or acute .............................. 5 
5a. DFO anterior to anus, about midway to gill openings; VF $15 / 66 / 182 \ldots \ldots \ldots \ldots \ldots \ldots$ ..................................... Scolecenchelys pubioilo (McCosker, 1979)

5b. DFO above or behind anus .

6a. Snout blunt; DFO above or slightly before anus; TV 131-136; MVF 48/50/134 ...... Scolecenchelys cookei (Fowler, 1928)

6b. Snout acute; DFO slightly behind anus; TV 126-136; MVF 51/51/131 . Scolecenchelys gymnota (Bleeker, 1857)

7a. Body entirely finless; coloration either uniform or darker dorsally, without large spots or saddles....................................................... 8

7b. At least a minute, short dorsal fin present; coloration variable, either uniform, banded, or spotted, or somewhat darker dorsally.

8a. Posterior nostril opening outside mouth, with a flap; anterior nostril tubular; body extremely elongate; head 15-20 times in TL; TV 156-166; MVF -/79/159....

Apterichtus flavicaudus (Snyder, 1904)

8b. Posterior nostril opening inside mouth; anterior nostril flush with snout; body moderately elongate; head 11-12 times in TL; TV 120-124; MVF -/47/122 ............ Ichthyapus vulturis (Weber \& de Beaufort, 1916)

9a. Only fin a short dorsal originating just behind occiput and ending in anterior trunk region; body extremely elongate, its depth 120-150 times in TL; TV 243-270;

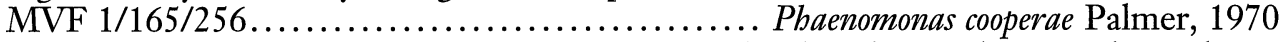

9b. Dorsal and anal fins present (pectoral fins absent), the dorsal extending nearly to the tail tip; body moderately to extremely elongate, but depth less than 120 times in

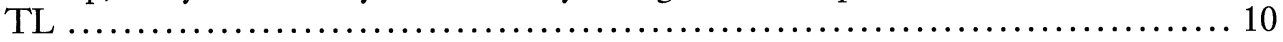

10a. Pectoral fins absent; DFO on nape; gill openings inferior, converging forward....... 11

10b. Pectoral fins present; DFO behind nape, either on head or slightly behind gill open-

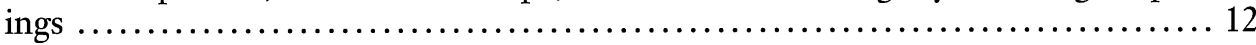

11a. Tail very short, about 3.2-3.6 times in TL; body cream-colored with a dark brown or black band along back from head to near tail tip; TV 192-205; MVF H/130/199 ..

11b. Tail longer, 2.4-2.8 times in TL; body yellow to cream, overlain with numerous yellow and brown to dark brown spots; TV 210-219; MVF H/124/214

Callechelys lutea Snyder, 1904

12a. DFO well in advance of gill openings; teeth molariform or granular; pectoral fins broad-based, short and rounded ...................................... 13

12b. DFO before, above, or behind gill openings; teeth pointed; pectoral-fin base restricted, opposite upper half of gill openings and longer than broad............ 14

13a. Coloration consists of several longitudinal series of dark spots along sides and dorsal surface; TV 17-183; MVF 2/76/180 ........... Myrichthys magnificus (Abbott, 1861)

13b. Coloration consists of about 30 dark saddles reaching approximately to the lateral line; TV 193-202; MVF 1/85/197................Myrichtbys colubrinus (Boddaert, 1781)

14a. DFO well ahead of gill openings; edge of upper lip fringed with a conspicuous row of barbels; TV 176-187; MVF 3/62/182 ....... Cirrbimuraena playfairii (Günther, 1870)

14b. DFO above or behind gill openings; upper lip either naked or fringed ............ 15

15a. Postorbital region with a conspicuous transverse depression; lips fringed; canine teeth in jaws and on vomer; coloration lacks large spots or bands, although lateral line pores may be darker than body 
15b. Dorsolateral profile of head even; lips entire; jaw and vomerine teeth not excessively developed; coloration uniform, spotted, or banded $\ldots \ldots \ldots \ldots \ldots \ldots \ldots \ldots \ldots \ldots \ldots \ldots$

16a. Snout very short, 13-19 times in HL; flesh above and behind eye not notably elevated to form a lateral ridge; body and tail spotting, if present, dark and limited to lateralline pores, with sparse dark spotting on dorsum of large specimens; dorsal fin and its base clear; TV 116-124; MVF 16/50/120

Brachysomophis crocodilinus (Bennett, 1833)

16b. Snout longer, 8-11 times in HL; flesh above and behind eye laterally elevated as a ridge; body and tail overlain with numerous dark spots on and above lateral line; dorsal-fin margin pale, its base distinctly black; TV 128-134; MVF 19/64/130.... Brachysomophis benshawi Jordan \& Snyder, 1904

17a. Conspicuous leaflike appendages on anterior nostrils; vomerine teeth absent; coloration pale; TV 157-172; MVF 9/76/168.... Phyllopbicbtbus xenodontus Gosline, 1951

17b. No leaflike appendages on anterior nostrils; vomerine teeth present or absent; color-

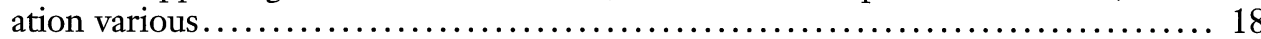

18a. Vomerine teeth absent or 1-3 present; head and body coloration light to tan, overlain with a series of 23-31 brown or black saddles equal to or wider than their pale interspaces; TV 164-171; MVF 9/71/168 ... Leiuranus semicinctus (Lay \& Bennett, 1839)

18b. A series of teeth on the vomer; coloration uniform or spotted, not as above........ 19

19a. DFO above pectoral tips; pectoral fin elongate, attenuate; coloration uniform, darker dorsally; TV 180-185; MVF 15/66/182 ......... Opbichthus kunaloa McCosker, 1979

19b. DFO above gill openings, in advance of pectoral-fin tips; pectoral fin rounded, not

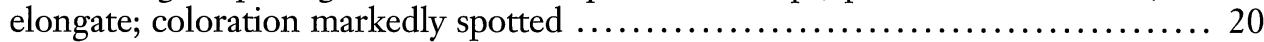

20a. Body overlain with 18-27 prominent dark saddles, a conspicuous wide saddle above the gill opening, and numerous golden to brown (in life) marblings on snout and face; TV 156-164; MVF 10/84/160 ............. Opbichthus bonaparti (Kaup, 1856)

20b. Body overlain with numerous dark or ocellated spots, those spots not appearing as saddles..................................................... 2

21a. Head and body overlain with numerous ocellated spots, those on body in three regular alternating rows, the spots separated by pale interspaces; TV 141-148; MVF $8 / 74 / 145 \ldots \ldots \ldots \ldots \ldots \ldots \ldots \ldots \ldots . . . \ldots$ Ophichthus polyophthalmus Bleeker, 1864

21b. Head and body overlain with numerous dark spots, those on body in two irregular rows, the spots about equal in size to their interspaces; TV 151-155; MVF $8 / 77 / 153$

Opbichtbus erabo (Jordan \& Snyder, 1901)

\section{NEW RECORDS AND TAXONOMIC CHANGES CONCERNING HAWAIIAN AND JOHNSTON ISLAND OPHICHTHIDS}

When the Hawaiian species of Muraenichthys were last treated (McCosker 1979) it was admittedly a polyphyletic group. Castle and McCosker (1999) subsequently examined most of the species of Muraenichthys and elevated the subgenus Scolecenchelys to include the majority of the valid species. The species of Scolecenchelys differ from those of Muraenichthys in the following manner: teeth conical and uniserial or blunt versus blunt and multiserial; two versus one cephalic pores between the anterior and posterior nostrils; and the posterior nostril opens into the mouth, covered partially or entirely by an exterior flap versus the posterior nostril opens outside the mouth, as a hole along the upper lip that is preceded by a flap. The Hawaiian species of Muraenichtbys is thus limited to $M$. 
schultzei and those of Scolecenchelys comprise $S$. cookei, S. gymnota, and S. pubioilo.

An adult specimen of Callechelys lutea, previously known from Hawai'i and the Northwestern Islands to Midway (McCosker 1979), was photographed and captured at Johnston Island in March 1996 by Phil Lobel. It was photographed underwater and then speared in the lagoon over a sand bottom with patch reefs at 6-8 $\mathrm{m}$ depth. The specimen, about 1 $\mathrm{m}$ long, was later discarded, but the photographs allow its identification with confidence.

The recent discovery of a second species of Callechelys from Hawai'i deserves mention. The genus was reviewed by McCosker (1998), who first mentioned the Hawaiian specimen of $C$. catostoma (most commonly known by its synonyms $C$. melanotaenia Bleeker and $C$. striatus Smith). The Hawaiian record is based on врвм 29292, an adult male with vivid coloration. A photograph of this species, based on an adult specimen from Palau, appears in McCosker (1998: fig. 4). The Hawaiian specimen has the following measurements (in $\mathrm{mm}$ ): total length 412; head 24.6; head and trunk 291; tail 121; predorsal distance 7.7; body depth at gill openings 6.4 ; snout 3.4 ; tip of snout to rictus 5.8; eye diameter 1.4 . It has 193 (123 preanal) vertebrae; throughout its range, C. catostoma has 192-205 vertebrae and a MVF of H/130/199 (McCosker 1998). The Hawaiian specimen was captured by J. E. Randall and party at Kailua, Kona, using rotenone over sand in $32 \mathrm{~m}$. Callechelys catostoma is widespread in the Tropics from Hawai'i, the Phoenix Islands, throughout Oceania, south to Lord Howe and north to the Ryukyus in the western Pacific, across the Indian Ocean to East Africa and the Red Sea. Its Hawaiian congener, $C$. lutea, is endemic to the Hawaiian Islands, occurring from the main islands to Midway (McCosker 1998) and Johnston Islands.

In their revision of the genus Myrichthys, McCosker and Rosenblatt (1993) examined the relationships of the two widespread IndoPacific species. They concluded that the common, spotted eels from Hawai' $i$, Midway, and Johnston Island, previously known as $M$. maculosus (Gosline 1951, McCosker 1979), differed enough in coloration and vertebral number from their western Pacific and Indian Ocean congeners to be recognized as $M$. magnificus (Abbott). As well, they placed several names in the synonymy of $M$. colubrinus (Boddaert), including Opbisurus fasciatus var. semicincta Bleeker, for which Gosline (1951:314) had created the substitute name Myricbthys bleekeri. The name of the blacksaddled Myrichtbys from Johnston Island (but not known from Hawai'i) thus becomes $M$. colubrinus.

The genus Brachysomophis was recently reviewed by McCosker and Randall (in press), and their conclusions affect the understanding of Hawaiian species. Brachysomophis benshawi was described by Jordan and Snyder (1904) on the basis of a specimen from Honolulu. To my knowledge, except for the holotype, there has been but one additional Hawaiian specimen of $B$. benshawi in a fish collection. Gosline (1951:317) examined "1 specimen, without locality but most probably from Oahu, inherited by the University of Hawaii Collection." I was unable to locate that specimen. In his report of the shore fishes of Johnston Island, Gosline (1952:443) reported on a specimen of "Brachysomophis sauropsis" (sio 69-232, formerly uH 1347, $356 \mathrm{~mm} \mathrm{SL}$ ) that he had compared to "... a 1070-mm specimen of Brachysomophis benshawi from Hawaii..." I presume the Hawaiian specimen to be that which Gosline referred to in 1951. Brachysomophis benshawi is widely distributed but known from only a few specimens from Polynesia, Micronesia, Melanesia, Japan, NE Australia, Indonesia, and Oman (McCosker and Randall in press). It has been captured by spear and ichthyocide between 0 and $35 \mathrm{~m}$, and occupies sand habitats, usually near or within coral or rocky reefs. Brachysomophis benshawi has been photographed in Hawai'i at Maui (Randall 1996:34, photographed at $10 \mathrm{~m}$; and by Nancy Harris, unpublished photos, taken at 27 and $34 \mathrm{~m}$ ).

Brachysomopbis crocodilinus (and its synonym $B$. sauropsis) is a wide-ranging species, known from Johnston Island, Micronesia, Melanesia, Polynesia, Japan, the Philippines, northern Australia, New Guinea, Indonesia, Chagos Archipelago, Mauritius, Comoros, Seychelles, Aldabra, and East Africa, but it is not yet 
known from Hawai $i$. It is generally collected in shallow lagoon sand, rock, and broken coral substrates, at depths of 0-2 m. Brachysomophis crocodilinus and $B$. benshawi are closely related but differ in the condition of their snout and interorbital region, their labial fringe development, their vertebral formulae, their maximum size $(817 \mathrm{~mm}$ versus 1006 $\mathrm{mm}$, respectively), and in their coloration.

In my previous review (McCosker 1979:63), I considered the Hawaiian population of Apterichtus flavicaudus (Snyder) to be conspecific with specimens from Rapa Island. Subsequent collections and examination of specimens from across Oceania to the western Indian Ocean now indicate that the Hawaiian population may in fact be unique (J. E. M. and D. Smith, unpubl. data).

Opbichthus kunaloa was described by McCosker (1979) on the basis of two complete specimens and a partially eaten specimen that were trapped in a benthic shrimp trap at $350 \mathrm{~m}$ depth southeast of Barbers Point, O'ahu. Three specimens were captured on 2 April 1981 by Paul J. Struhsaker aboard the fishing vessel Easy Rider Too. They were caught in a shrimp trap northeast of Hilo, off Hawai' $i$, at 220-260 fms (402-475 m) depth. The specimens (врвм 28120, $402 \mathrm{~mm}$, and сAs 47991, 383 and $423 \mathrm{~mm}$ ) do not differ in meristics, morphometrics, or coloration from the type material and expand our understanding of this species (Table 1).

\section{comments on Ophichthus bonaparti}

Bonapart's snake eel (Opbichthus bonaparti), also called the Brownsaddled snake eel, is a poorly known but wide-ranging species, previously known from South Africa to Indonesia and the western Pacific (McCosker and Castle 1986). Bleeker (1864:47) was correct as concerns this species when he wrote "C'est une des plus belles espèces de toute la famille." The first known Hawaiian specimen (врвм 38541) of the beautiful $O$. bonaparti was discovered by Bryan Seghorn in tide pools at Kaunolū on the south side of Lāna'i. Captured at 0200 hours on 20 September 1998, the specimen was fresh and intact when photographed by John E. Randall (Figure 1). It is

\section{TABLE 1}

Counts and Proportions (in Thousandths) of Opbichthus kunaloa (Based on Holotype, Intact Paratype, and Three Recently Collected Specimens)

\begin{tabular}{lcc}
\hline \hline Character $^{a}$ & Mean & Range \\
\hline TL (mm) & - & $383-473$ \\
HL/TL & 98 & $96-101$ \\
Head and trunk/TL & 403 & $398-410$ \\
Tail/TL & 597 & $590-602$ \\
Depth at gill opening/TL & 35 & $32-37$ \\
Dorsal fin origin/TL & 140 & $132-144$ \\
Pectoral fin length/HL & 410 & $319-476$ \\
Upper jaw/HL & 412 & $379-438$ \\
Snout/HL & 193 & $168-223$ \\
Eye/HL & 159 & $142-175$ \\
Predorsal vertebrae & 15 & $13-16$ \\
Preanal vertebrae & 66 & $63-67$ \\
Total vertebrae & 182 & $180-185$ \\
\end{tabular}

${ }^{a} \mathrm{TL}$, total length; HL, head length.

a female with minute, undeveloped ova. Its measurements (in $\mathrm{mm}$ ) are as follows: total length 863 ; head 92; trunk 403; tail 368; predorsal distance 98; pectoral-fin length 19; pectoral-fin base 10.3; body depth at gill openings 31 ; body width at gill openings 28 ; body depth at anus 28; body width at anus 27 ; snout 16.3 ; tip of snout to rictus 37.8 ; eye diameter 9.5; interorbital distance 13; gill opening height $\sim 11$; isthmus width $\sim 20$. It has $11 / 80 / 156$ vertebrae. I examined the holotype of O. bonaparti (MNHN B-2755); it is in adequate condition and has $9 / 89 / 164$ vertebrae.

The taxonomy of Opbichtbus bonaparti is fraught with mystery and confusion. My examination of specimens of and literature concerning this eel has resulted in the identification of several names with this species. Summarized below are my taxonomic conclusions concerning $O$. bonaparti and its synonyms:

Poecilocephalus Bonaparti Kaup, 1856a:43; 1856b:5, pl. 1, fig. 2 (holotype MNHN B2755, Ambon I., Moluccas Is., Indonesia).

Ophisurus chrysospilos Bleeker, 1857:8, 27, 88 (not available; appeared in list on p. 8 and p. 27 and in the synonymy of Ophisurus bonapartei [sic] Kaup on p. 88). New synonymy. 


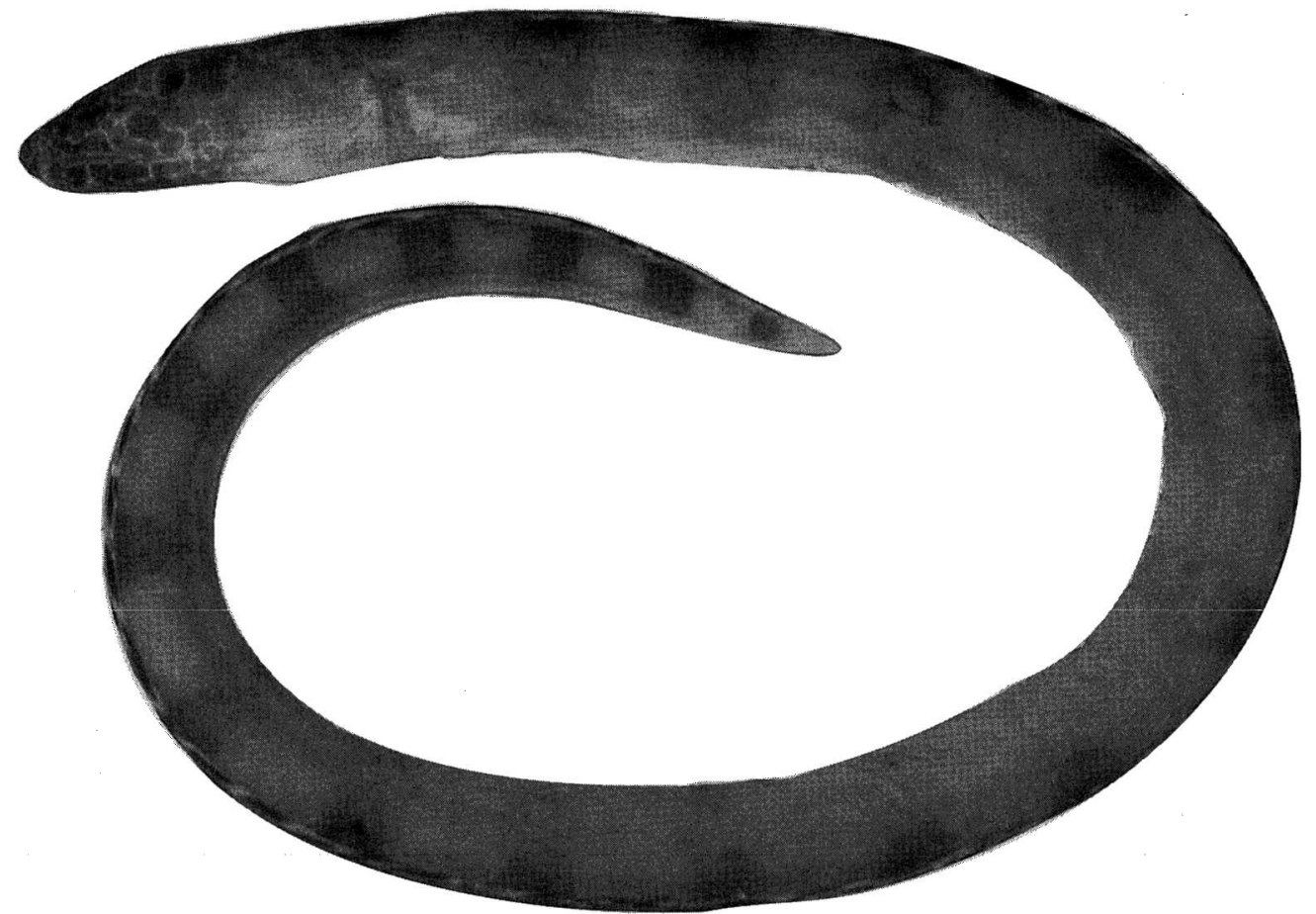

Figure 1. Opbichthus bonaparti from Kaunolū, Lāna'i, врвм 38541, 863 mm TL. (Photograph by J. Randall.)

Poecilocephalus Markworti Kaup, 1860:10, pl. 1, fig. 1 (type specimen, presumed to be in the Hamburg Museum, is lost; no locality or specimen number given). New synonymy.

Ophichthys episcopus Castelnau, 1878:244 (holotype unknown, Moreton Bay, Queensland, Australia). New synonymy.

Opbichthys garretti Günther, 1910:397, pl. 163, fig. A (holotype unknown, Society Islands). New synonymy.

At its inception, Poecilocephalus bonaparti was published twice by Kaup in 1856 (see expanded discussion concerning Kaup in McCosker 1977:56). The earlier treatment, "Uebersicht der Aale" (Kaup 1856a), is mentioned by John Edward Gray in the preface of the latter, the Catalogue of apodal fish, in the collection of the British Museum (Kaup 1856b), which was published on 30 December 1856. The plates did not appear in the earlier version. Kaup altered several names in the latter work, but none concerned bonaparti. Following Eschmeyer (1998), I recognize that $1856 a$ has priority. In the following year, Bleeker listed Opbisurus chrysospilos (1857) in his treatment of Ambon fishes on pages 8 and 27 (identifying it as "n. spec." on p. 27), then synonymized it with Opbisurus bonapartei $[$ sic] on p. 88 of the same paper. Kaup (1860) described and illustrated Poecilocephalus markworti but provided neither a museum number nor a capture locality for the specimen. Kaup's specimen of markworti is undoubtedly O. bonaparti, as Bleeker (1864:47) clearly explained when synonymizing it. Castelnau (1878) described Opbichthys episcopus on the basis of a specimen from Moreton Bay, Australia. The staff of the Australian Museum (Sydney) and I attempted without success to find Castelnau's specimen. It is clear from the description that it too is $O$. bonaparti. Günther (1910:397) described and illustrated Ophichthys garretti on the basis of an approximately $60-\mathrm{cm}$ specimen from the Society Is- 
lands. The current location of the holotype is unknown, but the description and illustration clearly indicate that it is a specimen of $O$. bonaparti. Fowler (1928:45) proposed that Microdonophis fowleri Jordan \& Evermann (1903) and Ophichtbus garretti were junior synonyms of Ophichthus polyophthalmus Bleeker, but subsequently (Fowler 1935:369) resurrected fowleri, considered garretti to be its synonym, and described Ophichthus retifer as new. McCosker and Castle (1986) examined the holotype of retifer and determined that it is a junior synonym of $O$. erabo. The type of retifer is nearly identical in coloration and proportions to specimens of erabo; however, it has 7/77/143 vertebrae, a total number more comparable with that of polyophthalmus. I consider the tail of the type of $O$. retifer to have been damaged and healed, resulting in the low vertebral count.

Color underwater photographs of living specimens of Opbichtbus bonaparti have recently been published. These include those by Nomura (1996:1) from 19 m depth, Kochi Prefecture, Japan, and by Michael (1998:304305) of specimens from northeastern Sulawesi and Ambon, Indonesia, at 2.5-8 m depth. Michael's photographs illustrate the color variation of the head of three specimens, ranging from brown markings overlaying a yellow gold head to golden brown markings on a white head to dark brown on white. Michael stated that "Bonapart's Snake Eel is found near coastal reefs and forereef slopes, on sand and mud bottoms, at depths of 1.5 to $20 \mathrm{~m}$. In certain places, a number of these eels can be found living in the same area with at least $2 \mathrm{~m}$ between specimens. Ophichthus bonaparti is sometimes seen with its head sticking out from the substrate during the day, but more individuals are observed at night." I have received other excellent photographs taken by Robert Patzner of this species from the Maldives and from northern Sulawesi.

\section{DISTRIBUTION OF HAWAIIAN OPHICHTHIDS}

Any discussion of Hawaiian shorefish distribution is complicated by several factors, including the level of uniqueness considered (endemism at the specific or subspecific lev- el?); the extralimital discovery of a Hawaiian waif (does that preclude Hawaiian endemicity?); the significance of nonbreeding extralimital waifs in Hawaiian waters (at what population level should nonbreeding individuals be considered part of the Hawaiian ichthyofauna?); and sampling bias, such that species from poorly sampled regions (including deep water and complex lava substrates) appear rarer than they actually are. Randall (1976, 1992, 1998) discussed these issues and considered subspecific difference to be adequate for endemism, that the single extralimital appearance of an endemic species invalidates its endemicity, and that a single appearance by an extralimital establishes its presence (albeit temporary) within the fauna. I have followed his assumptions. Randall (1976, 1992, 1998) also substantiated Gosline and Brock's (1960) discovery that endemic Hawaiian shorefish species are often more abundant than more widespread forms, a fact that is borne out by most Hawaiian ophichthids.

When I last reviewed the distribution of the Hawaiian and Johnston Island ophichthids (McCosker 1979:65-66), I recognized five of the 15 known Hawaiian species as endemics. Five additional species were known to reach Johnston but not the Hawaiian Islands. The subsequent extralimital capture of $\mathrm{Bra}$ chysomophis benshawi (thought to have been a Hawaiian endemic), the capture of Callecbelys lutea at Johnston, the discovery of the widespread Indo-Pacific species Callechelys catostoma and Ophichtbus bonaparti in Hawai' $\mathrm{i}$, and the recognition of Apterichtus flavicaudus and Myricbthys magnificus as probably Hawaiian endemics do not dramatically alter the previous assumption. The addition of Callechelys lutea to the Johnston Island ichthyofauna raises the total species list to 302 (Kosaki et al. 1991), of which nine are ophichthids.

I now assume that five of the 17 species (29.4\%) from Hawai' $i$ and the Northwestern Hawaiian Islands (or five of the 22 species [22.7\%] if Johnston Island is included) are endemic, a level of endemism comparable with the $23.1 \%$ given by Randall (1998) for the entire shorefish fauna. It is noteworthy that moray eels, although possessing a leptocephalus larva as do all anguilliform fishes, 
TABLE 2

Distribution of Hawaiian and Johnston Island Ophichthids

\begin{tabular}{|c|c|c|c|c|}
\hline Species & $\begin{array}{l}\text { Main Hawaiian } \\
\text { Islands }\end{array}$ & $\begin{array}{l}\text { Northwestern } \\
\text { Islands }\end{array}$ & $\begin{array}{l}\text { Johnston } \\
\text { Island }\end{array}$ & $\begin{array}{c}\text { Indo-West } \\
\text { Pacific }\end{array}$ \\
\hline Schultzidia jobnstonensis & $\mathrm{x}$ & $\mathrm{x}$ & $\mathrm{x}$ & $\mathrm{x}$ \\
\hline Schismorbynchus labialis & & & $\mathrm{x}$ & $\mathrm{x}$ \\
\hline Muraenicbthys scbultzei & & & $\mathrm{x}$ & $\mathrm{x}$ \\
\hline Scolecenchelys cookei & $\mathrm{x}$ & $\mathrm{x}$ & & \\
\hline Scolecenchelys gymnota & & & $\mathrm{x}$ & $\mathrm{x}$ \\
\hline Scolecenchelys pubioilo & $\mathrm{x}$ & & & \\
\hline Aptericbtus flavicaudus & $\mathrm{x}$ & $\mathrm{x}$ & & \\
\hline Icbtbyapus vulturis & $\mathrm{x}$ & $\mathrm{x}$ & & $\mathrm{x}$ \\
\hline Callechelys catostoma & $\mathrm{x}$ & & & $\mathrm{x}$ \\
\hline Callechelys lutea & $\mathrm{x}$ & $\mathrm{x}$ & $\mathrm{x}$ & \\
\hline Myricbtbys colubrinus & & & $\mathrm{x}$ & $\mathrm{x}$ \\
\hline Myrichthys magnificus & $\mathbf{x}$ & $\mathrm{x}$ & $\mathrm{x}$ & \\
\hline Cirrbimuraena playfairii & $\mathrm{x}$ & $\mathrm{x}$ & & $x$ \\
\hline Pbyllophicbtbus xenodontus & $\mathrm{x}$ & & & $\mathrm{x}$ \\
\hline Phaenomonas cooperae & $\mathrm{x}$ & & & $\mathrm{x}$ \\
\hline Leiuranus semicinctus & $\mathrm{x}$ & $\mathrm{x}$ & $\mathrm{x}$ & $\mathrm{x}$ \\
\hline Brachysomophis crocodilinus & & & $\mathrm{x}$ & $\mathrm{x}$ \\
\hline Brachysomophis benshawi & $\mathrm{x}$ & & & $\mathrm{x}$ \\
\hline Ophichthus bonaparti & $\mathrm{x}$ & & & $\mathrm{x}$ \\
\hline Ophichtbus erabo & $\mathrm{x}$ & & & $\mathrm{x}$ \\
\hline Ophichtbus kunaloa & $\mathrm{x}$ & & & \\
\hline Ophicbtbus polyopbthalmus & $\mathrm{x}$ & & & $\mathbf{x}$ \\
\hline
\end{tabular}

have a considerably lower degree of Hawaiian endemism than do the ophichthids. Böhlke and Randall (2000) found that only four (or possibly only three) of 40 (10\%) Hawaiian morays are endemic. If the five Johnston Island Indo-Pacific species are included, endemism is reduced to $4 / 45(8.9 \%)$. They also reported that 23 of the $40(57.5 \%)$ Hawaiian morays are found in the Indian Ocean. Eight of 17 (47\%) of Hawaiian (excluding Johnston Island) ophichthids (although three are known from single Hawaiian specimens) enter the Indian Ocean (McCosker and Castle 1986). Ten Hawaiian muraenids have crossed the eastern Pacific barrier (McCosker and $\mathrm{Hu}-$ mann 1996); however, no Hawaiian ophichthids or congrids have done so. The wideranging nature of the morays, as contrasted with the limited distribution of ophichthids, remains unexplained.

Three shallow-water Indo-Pacific ophichthid species are known from but a single Hawaiian specimen (Callechelys catostoma, Ophichthus bonaparti, and Phaenomonas coop- erae), indicating that they are probably sporadic visitors and are not established colonizers. The deep-water Hawaiian ophichthids (Opbichtbus erabo, O. kunaloa, $O$. polyopbthalmus, and Scolecenchelys pubioilo) are known from few specimens whose habitus and abundance will likely become understood as a result of future deep trapping efforts and submersible operations.

Five Indo-Pacific species (Brachysomophis crocodilinus, Muraenichthys schultzei, Myrichthys colubrinus, Schismorbynchus labialis, and Scolecenchelys gymnota) are still known from Johnston Island but not the Hawaiian chain. Because most are abundant and shallow-water species, it seems unlikely that their absence from Hawai'i is a result of inadequate collecting but rather indicates that their larvae are unable to reach or find appropriate habitat in the Hawaiian Islands. (The fact that Brachysomophis crocodilinus is known from Johnston Island by but a single specimen might be explained by the low collecting effort at Johnston or that it too is a waif.) 
The understanding of Hawaiian ophichthids is by no means complete. Extensive analysis remains to be done involving the relationship of many apparently widespread Indo-Pacific ophichthid species before assumptions of Hawaiian endemism can be established. It is likely, now that the vertebral formulas for all Hawaiian ophichthids are known, that the identification of leptocephali will assist in the explanation of the gene flow between Indo-Pacific populations and those of Hawai'i and Johnston Island.

As I concluded two decades ago in my review of Hawaiian ophichthids, I now reaffirm that "Untaxing the taxonomy of the Hawaiian ophichthids, initiated by Maui the Wonder Boy and continued by Jordan, Evermann, and Gosline, remains a challenge."

\section{ACKNOWLEDGMENTS}

I thank the many individuals who have generously assisted me during the course of this study, including but not limited to: William N. Eschmeyer for nomenclatorial advice and his reading of a draft of the manuscript; Julie Mounts for assistance with radiographs; Hiroshi Senou for advice and translations; Scott Michael for sharing his observations of living specimens; and Phil S. Lobel (Boston University) for his advice on Johnston Island eels. I particularly thank John E. Randall for reading a draft of the manuscript, for the use of his photograph, and for sharing his knowledge of Hawaiian fishes. Many curators and collection managers have generously allowed me to examine specimens and radiographs in their care, including Eugenia B. Böhlke (ANSP); John R. Paxton, Douglass Hoese, and Mark McGrouther (AMS); Oliver Crimmen (BMNH); Arnold Suzumoto and John E. Randall (врвм); Dave Catania, William N. Eschmeyer, Jon Fong, and Tomio Iwamoto (CAS); Patrice Pruvost (MNHN); Richard H. Rosenblatt and H. J. Walker (sio); William A. Gosline (then of University of Hawai ${ }^{i}$ ); and David Smith and Jeffrey Williams (USNM). Portions of this project were accomplished during my tenure as a visiting fellow at the Australian Museum (Sydney).

\section{Literature Cited}

Bleeker, P. 1857. Achtste bijdrage tot de kennis der vischfauna van Amboina. Acta Soc. Sci. Indo-Neerl. 2:1-102.

1864. Atlas ichthyologique des Indes Orientales Néêrlandaises, publié sous les auspices du gouvernement colonial. Tome 4, Murènes, Synbranches, Leptocéphales. Leiden. 132 pp., pl. 145-193.

Böhlke, E. B. 1982. Vertebral formulae of type specimens of eels (Pisces: Anguilliformes). Proc. Acad. Nat. Sci. Phila. 134:31-49.

Böhlke, E. B., and J. E. Randall. 2000. A review of the moray eels (Anguilliformes: Muraenidae) of the Hawaiian Islands, with descriptions of two new species. Proc. Acad. Nat. Sci. Phila. 150:203-278.

Castelnau, F. L. 1878. Australian fishes. New or little known species. Proc. Linn. Soc. N. S. W. 2 (3): 225-248.

Castle, P. H. J., and J. E. McCosker. 1999. A new genus and two new species of myrophine worm-eels, with comments on Muraenichthys and Scolecenchelys (Anguilliformes: Ophichthidae). Rec. Aust. Mus. 51 (2): 113-122.

Colum, P. 1937. Legends of Hawaii. Yale University Press, New Haven. 220 pp.

Eschmeyer, W. N., ed. 1998. Catalog of fishes. Spec. Publ. Calif. Acad. Sci. 3 vols. 2905 pp.

Fowler, H. W. 1928. The fishes of Oceania. Bernice P. Bishop Mus. Mem. 10. 540 pp. . 1935. South African fishes received from Mr. H. W. Bell-Marley in 1935. Proc. Acad. Nat. Sci. Phila. 87:361-408.

Gosline, W. A. 1951. The osteology and classification of the ophichthid eels of the Hawaiian Islands. Pac. Sci. 5:298-320.

- 1952. The inshore fish fauna of Johnston Island, a central Pacific atoll. Pac. Sci. 9:442-480.

Gosline, W. A., and V. E. Brock. 1960. Handbook of Hawaiian fishes. University of Hawai'i Press, Honolulu. 372 pp.

Günther, A. A. 1870. Catalogue of the fishes in the British Museum. Vol. 8. Catalogue of the Physostomi, containing the families Gymnotidae ... in the British Museum. British Museum, London. xxv + 549 pp. 
1910. Andrew Garrett's Fische der Südsee. Band III, Heft IX. L. Friederichsen \& Co., Hamburg. i-vi + 389-515 pp., pls. 161-180.

Jordan, D. S., and B. W. Evermann. 1903. Descriptions of new genera and species of fishes from the Hawaiian Islands. Bull. U.S. Fish Comm. 22:161-208.

- 1905. The aquatic resources of the Hawaiian Islands. Part I. The shore fishes of the Hawaiian Islands, with a general account of the fish fauna. Bull. U.S. Fish Comm. 23:i-xxviii, 1-574, pls. 1-65, color pls. 1-73.

Jordan, D. S., and J. O. Snyder. 1904. Notes on collections of fishes from Oahu Island and Laysan Island, Hawaii, with descriptions of four new species. Proc. U.S. Natl. Mus. 27 (1377): 939-948.

Kaup, J. J. 1856a. Uebersicht der Aale. Arch. Natur. 22 (1): 41-77.

- 1856b. Catalogue of apodal fish, in the collection of the British Museum. British Museum, London. viii + 163 pp.

. 1860. Neue aalaehnliche Fische des Hamburger Museums. Abh. Geb. Naturwiss. Hersg. Naturwiss. Ver. Hambg. 4 (2): $1-29+4$ pp.

Kosaki, R. K., R. L. Pyle, J. E. Randall, and D. K. Irons. 1991. New records of fishes from Johnston Atoll, with notes on biogeography. Pac. Sci. 45:186-203.

Leviton, A. E., R. H. Gibbs Jr., E. Heal, and C. E. Dawson. 1985. Standards in herpetology and ichthyology: Part I. Standard symbolic codes for institutional resources collections in herpetology and ichthyology. Copeia 1985:802-832.

McCosker, J. E. 1977. The osteology, classification, and relationships of the eel family Ophichthidae. Proc. Calif. Acad. Sci. ser. 4, 41 (1): 1-123.

. 1979. The snake eels (Pisces, Ophichthidae) of the Hawaiian Islands, with the description of two new species. Proc. Calif. Acad. Sci. ser. 4, 42 (2): 5767.

1998. A revision of the snake-eel genus Callechelys (Anguilliformes: Ophichthidae) with the description of two new Indo-Pacific species and a new callechelyin genus. Proc. Calif. Acad. Sci. 50 (7): 185215.

McCosker, J. E., and P. H. J. Castle. 1986. Family Ophichthidae. Pages 176-186 in M. Smith and P. Heemstra, eds. The sea fishes of southern Africa. Macmillan, Johannesburg.

McCosker, J. E., and P. Humann. 1996. New records of Galápagos fishes. Not. Galapagos 56:18-22.

McCosker, J. E., and J. E. Randall. A revision of the snake-eel genus Brachysomophis (Anguilliformes: Ophichthidae), with the description of two new species and comments on the species of Mystriophis. IndoPac. Fishes (in press).

McCosker, J. E., and R. H. Rosenblatt. 1993. A revision of the snake eel genus $M y r-$ ichthys (Anguilliformes: Ophichthidae) with the description of a new eastern Pacific species. Proc. Calif. Acad. Sci. 48 (8): 153169.

Michael, S. W. 1998. Reef fishes. Vol. 1. A guide to their identification, behavior, and captive care. Microcosm, Vermont. 623 pp.

Nomura, T. 1996. Irezumi-umihebi, Opbichthus bonaparti (Kaup). I. O. P. Diving News 7 (3): 1 (in Japanese).

Pukui, M. K. 1902. Ka hana kuhikuhi no ka lawai'a ana. Ka Nupepa Kuokoa. Newspaper article, 23 May. (Not seen: reference from M. Titcomb, 1972, Native use of fish in Hawaii. University of Hawai' $i$ Press, Honolulu, 175 pp.)

Randall, J. E. 1976. The endemic shore fishes of the Hawaiian Islands, Lord Howe Island and Easter Island. Trav. Doc. O.R.S.T.O.M. 47:49-73.

- 1992. Endemism of fishes in Oceania. In Coastal resources and systems of the Pacific basin: Investigation and steps toward protective management. U.N. Environ. Programme Reg. Seas Rep. Stud. 147:55-67.

. 1996. Shore fishes of Hawaii. Natural World Press, Vida, Oregon. 216 pp.

- 1998. Zoogeography of shore fishes of the Indo-Pacific region. Zool. Stud. 37 (4): $227-268$.

Smith, D. G. 1994. Catalogue of type specimens of recent fishes in the National 
Museum of Natural History, Smithsonian Institution. 6: Anguilliformes, Saccopharyngiformes and Notacanthiformes (Teleostei: Elopomorpha). Smithson. Contrib. Zool. 566. 50 pp.
Weber, M., and L. F. de Beaufort. 1916. Fishes of the Indo-Australian Archipelago. Vol. 3. Ostarophysi: II Cyprinoidea, Apodes, Synbranchi. E. J. Brill, Leiden. 455 pp. 